\title{
PERKEMBANGAN SPASIAL HUNIAN SUKU BAJO DI KAMPUNG WURING KOTA MAUMERE
}

\author{
Ambrosius A. K. S. Gobang, Antariksa, Agung Murti Nugroho \\ Magister Arsitektur Lingkungan Binaan, Fakultas Teknik, Universitas Brawijaya \\ Jl. M. T. Haryono, No. 167, Malang, Jawa Timur \\ Email: aagobangg@gmail.com
}

\begin{abstract}
Abstrak
Kondisi spasial hunian Suku Bajo di kampung Wuring Kota Maumere dilihat pada karakteristik hunian masyarakat sebagai kampung awal peradaban muslim dan menjadi pusat penyebaran agama Islam di Kabupaten Sikka. Latar belakang sejarah sebagai tinjauan dalam menggali terbentuknya hunian masyarakat serta aspek geografis, sosial, budaya dan ekonomi masyarakat setempat. Pendekatan dalam penelitian ini menggunakan metode fenomenologi dengan analisis deskriptif kualitatif dan bersifat naturalistik yaitu menggambarkan dan menginterpretasi catatan budaya Suku Bajo berupa keterangan sejarah, dokumen peta, maupun artefak yang berwujud fisik hunian masyarakat Suku Bajo. Tujuan penelitian ini untuk mengkaji perkembangan spasial yang terbentuk berupa sistem spasial hunian dan aspek-aspek yang melandasi pembentukan spasial hunian Suku Bajo pada kawasan kampung Wuring sebagai upaya untuk memahami kondisi awal hingga terbentuknya hunian kampung saat ini. Hasil penelitian memberikan gambaran tentang sistem spasial hunian mencakup organisasi ruang, orientasi ruang dan hirarki ruang dalam lingkup mikro hunian berupa konsep ma'bunda-ma'buli. Selain itu gambaran perkembangan spasial hunian berupa bentuk panggung tumbuh dan panggung diaruma yang berdampak terhadap messo lingkungan karena adanya aspek non fisik yang melandasi pembentukan spasial hunian di kawasan kampung Wuring.
\end{abstract}

Kata kunci: spasial, hunian, suku Bajo, kampung Wuring

\begin{abstract}
Title: Spatial Development of Bajo Tribal Residence in Wuring Village Maumere City

The spatial condition of the Bajo Tribe at Wuring village in Maumere Town is seen in the characteristics to residential community as early village of Muslim civilization and became the center of spreading out Islam in Sikka Regency. The historical background is as a review in exploring the formation's community dwelling and geographical, social, cultural and economic aspects of the local community. This approach in research using phenomenology method with qualitative descriptive and naturalistic analysis that is describing and interpreting cultural record of Bajo Tribe in the form of description of history, map document, or artefact which in the form of physical resident of Bajo tribe society. The purpose of this study is to examine the spatial development that is formed in the form of spatial system to residential and the aspects underlying the spatial establishment of Bajo Tribe in Wuring village area as an effort to understand the initial condition until the formation of the present kampung hamlet. The result of this research gives general ilustration about occupancy spatial system including space organization, space orientation and space of hierarchy in micro scope of residence in the form of ma'bunda-ma'buli concept. On the other hand, it is also on environmental messo like form of spatial development shelter in the form of grow stage and diaruma stage because of the nonphysical aspect underlined spatial formulation of dwellings to the area of Wuring village.
\end{abstract}

Keywords: spatial, dwelling, Bajo tribe, Wuring village 


\section{Pendahuluan}

Hunian di perairan laut pada kawasan pesisir di Indonesia umumnya terbentuk secara berkelompok. Kelompok hunian yang terbentuk sebagai hasil pemikiran untuk menetap bagi masyarakat bahari terutama di daerah pesisir pada rute pelayaran dan perdagangan di Asia Tenggara. Daerah pesisir sangat berkaitan dengan eksistensi masyarakat nelayan yaitu bahwa masyarakat nelayan hidup, tumbuh dan berkembang di kawasan pesisir atau kawasan transisi antara daratan dan lautan (Kusnadi, 2009).

Hunian di pesisir adalah hunian yang secara fisik terletak di daerah transisi antara wilayah daratan dan lautan dengan mayoritas masyarakat berprofesi sebagai nelayan. Masyarakat nelayan ini terbentuk sebagai komunitas dengan kebudayaan yang dipengaruhi oleh sistem nilai dan simbol masyarakat maritim untuk membentuk huniannya. Nuansa kebersamaan tempat di pesisir adalah adanya tempat bersama melalui pengaturan jarak antar setiap hunian (Nugroho, 2015).

Proses terbentuknya hunian masyarakat Suku Bajo di kampung Wuring sampai saat ini, tidak lepas dari kondisi geografis dan lingkungan alam dan kegiatan keseharian warga sebagai nelayan atau pelaut. Meski demikian, masyarakat di kawasan ini juga menginginkan perkembangan yang bersifat positif pada lingkungan huniannya. Proses perkembangan terlihat pada beberapa bangunan hunian. Kampung Wuring dipilih sebagai lokus dalam kajian ini karena telah menjadi tempat tinggal masyarakat yang identik dengan orang Bajo yang hidup di atas laut dan cukup berdampak pada perkembangan regional kawasan Kota Maumere. Selain itu belum adanya kajian yang masif tentang eksistensi hunian Suku Bajo di kampung Wuring ini. Letaknya yang strategis sebagai pelabuhan menjadi pusat perdagangan sekaligus pusat penyebaran agama Islam. Kampung nelayan tradisional di Wuring kini telah ditetapkan oleh Pemerintah Kabupaten Sikka menjadi destinasi wisata bagi wisatawan domestik maupun internasional.

\section{Metode}

Perkembangan spasial hunian dikaji dengan cara kerja kualitatif, khususnya fenomenologi. Penekanan pada segala bentuk fakta atau peristiwa sosial yang dapat dilihat secara ilmiah (Moleong, 2002). Pemilihan pendekatan dilandasi pemahaman bahwa aspek manusia dan kemanusiaannya yang amat kaya dan terkait tata keruangan arsitektural.

Pemahaman hunian menurut UU No. 1 Tahun 2011 tentang Perumahan dan Permukiman, dilihat dari pengertian rumah adalah bangunan yang berfungsi sebagai tempat tinggal atau hunian dan sarana pembinaan keluarga. Rumah adalah bagian yang utuh dari permukiman, dan bukan hasil fisik sekali jadi semata, melainkan merupakan suatu proses yang terus berkembang dan terkait dengan mobilitas sosial ekonomi penghuninya. Ada interaksi antara rumah dan penghuni yaitu apa yang diberikan rumah kepada penghuni serta apa yang dilakukan penghuni terhadap rumah (Turner, 1972). Terminologi hunian digunakan dalam kajian ini karena mengandung makna rumah 
secara fisik dan penghuni yang berkontribusi terhadap perkembangan spasialnya.

Tata ruang adalah hubungan organisatoris pada sebuah lingkungan fisik yang terdiri dari berbagai macam objek dan manusia, yang dibentuk melalui ruang-ruang tertentu (Antariksa, 2011). Setting merupakan tatanan ruang atau tata letak dari suatu interaksi antara manusia dengan lingkungannya yang dapat dilihat dari beberapa variabel yaitu ruang, waktu, aktivitas dan pelaku (Rapoport, 1990). Kajian setting spasial yang dimaksud adalah tatanan perilaku dalam ruang fisik yang menjadi tempat beraktivitas dan berinteraksi antar individu dan antara individu dengan lingkungannya. Spasial atau spasi bermakna jarak, ruang antara bidang atau ruang di antara benda-benda (UU Nomor 4 Tahun 2011 tentang Informasi Geospasial). Pemaknaan spasial adalah ruang fisik yang dibangun pada kawasan hunian, rumah tinggal dan bentuk bangunan oleh adanya beberapa faktor yang berkembang di lingkungan masyarakat (Mulyati dalam Prihanto, 2006). Sistem spasial merupakan aspek mendasar dan paling stabil karena terbentuk sesuai dengan pola tingkah laku manusia. Sistem spasial berkaitan dengan organisasi ruang, orientasi ruang dan hirarki ruang (Habraken dalam Ciptadi, 2014). Dalam kaitan penelitian ini maka spasial hunian yang dibentuk oleh masyarakat Suku Bajo merupakan suatu peristiwa yang nyata dan perlu dikaji lebih jauh tentang perkembangan secara fisik yang dapat dilihat dengan pendekatan teori sistem spasial serta aspek-aspek yang ada dalam kehidupan sosial budaya masyarakat yang dapat dilihat dengan pendekatan teori setting spasial.

Data yang dikumpulkan meliputi : data fisik (organisasi ruang, orientasi ruang, hirarki ruang, hubungan ruang, zona, tata letak bangunan) dan data non fisik (sosial, agama, mata pencaharian, pengetahuan, dan pola hidup).

Analisis dilakukan secara kualitatif terhadap wujud fisik yang muncul dari proses sosial budaya masyarakat untuk dapat dilihat pengaruhnya terhadap munculnya perkembangan spasial hunian. Analisa sistem spasial dan setting spasial dilakukan pada skala ruang hunian dan lingkungan. Pendekatan tipologi dilakukan untuk mempelajari konsep serta sistem spasial masing-masing kasus hunian. 


\section{Hasil dan Pembahasan}

\section{Tinjauan Obyek Studi}

Menurut cerita sejarah dari hasil wawancara dengan tokoh masyarakat menyebutkan bahwa orang Bajo dari Pulau Permaan masuk pertama kali ke Maumere melalui wilayah Tou. Awal komunitas suku Bajo di Tou berjumlah 17 kepala keluarga, dikepalai oleh seorang kepala kampung yang dikenal dengan nama Pijung Juma. Tokoh Pijung Juma ini menjalin hubungan baik dengan Raja Sikka yang dijuluki Moang Bako Kikir Hiwa (Berjari Sembilan). Kampung Wuring juga masuk dalam lingkup pembangunan dan pemerintahan Kerajaan Sikka sejak zaman Don Thomas Ximenes da Silva (1922-1954). Raja Thomas memperkenankan orang-orang dari suku Bajo masuk di kampung Wuring. Potensi Wuring sebagai bandar dagang yang ramai menjadikan tempat ini sebagai gerbang masuk dan terjadinya asimilasi berbagai budaya.

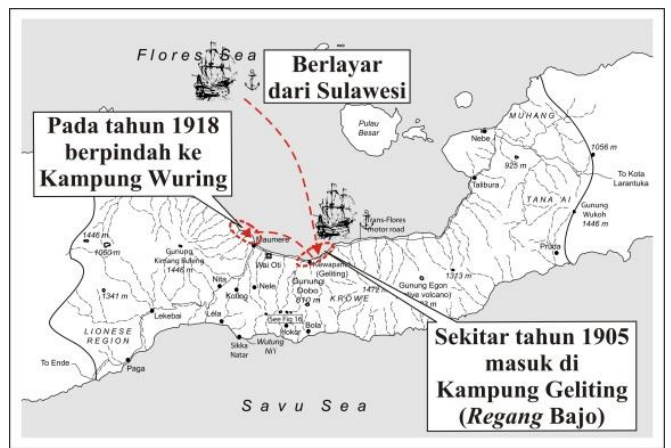

Gambar 1. Peta pergerakan suku Bajo

Sumber: Dinas Pariwisata Kab. Sikka, 2017

Berdasarkan perkembangan fisik spasial kampung, masyarakat Suku Bajo membagi kampung Wuring ini dalam 3 (tiga) bagian yaitu Wuring Leko sebagai awal pembentukan kampung, Wuring Tengah (tangah) dan Wuring Laut (toroh). Dari hasil wawancara dijelaskan bahwa perkembangan kampung Wuring ini dimulai dari leko atau area sekitar teluk
Maumere dan cenderung berkembang ke arah utara mengikuti pola taka. Kata taka dalam bahasa Bajo adalah koral atau gugusan karang dalam laut dan dangkal. Di atas taka ini kemudian masyarakat Suku Bajo melakukan aktivitas menangkap ikan dengan memarkir sampan atau rumah perahu yang lama kelamaan masyarakat menanam tiang-tiang lalu membangun huniannya dan perlahan-lahan menimbun taka tersebut menjadi daratan. Kecenderungan ini dapat menjelaskan keadaan kampung Wuring saat ini yaitu Wuring Tengah dan Wuring Laut yang sudah menjadi daratan itu awalnya adalah perairan dengan taka yang ditimbun oleh masyarakat Suku Bajo.

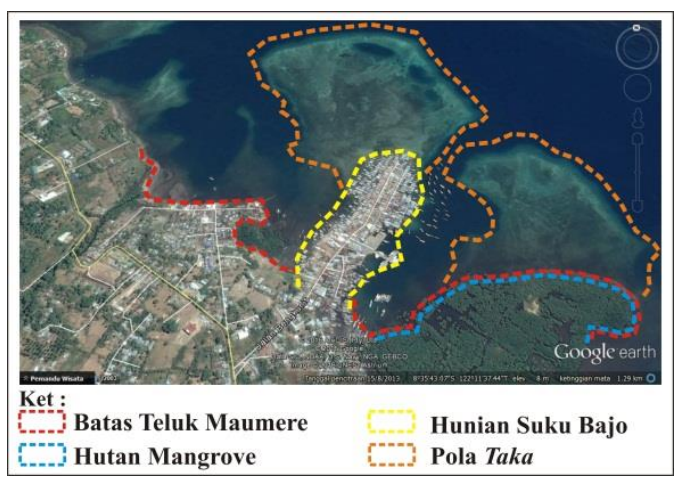

Gambar 2. Pola taka di teluk Maumere Sumber: Google Earth, 2017

Suku Bajo selalu memilih tempat tinggal yang tidak jauh dari air laut, karena hampir seluruh hidupnya bergantung dari hasil laut. Hunian dengan bentuk panggung sederhana dihiasi perahu atau sampan kecil di depannya, sehingga terlihat halamannya berupa air laut. Pembagian zona hunian Suku Bajo di pesisir Wuring ini mengikuti tahapan perkembangan fisik kampung dari upaya oleh masyarakat Suku Bajo sendiri dengan menimbun taka secara perlahan-lahan dimulai dari Wuring Leko berkembang ke utara menjadi 
Wuring Tengah dan berkembang lagi ke utara menjadi Wuring Laut.

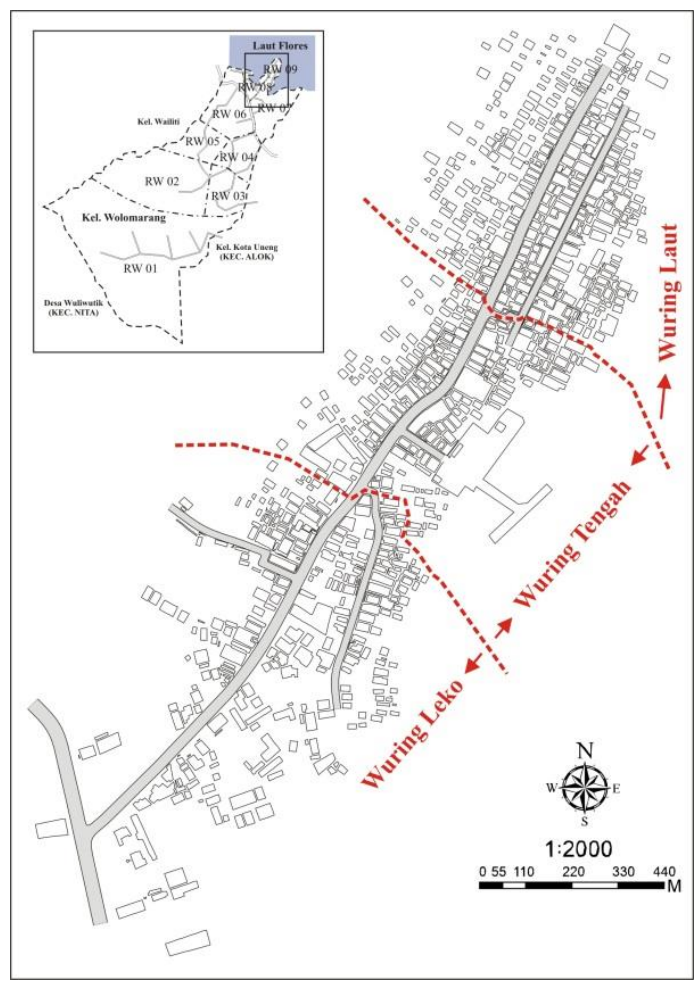

Gambar 3. Peta kampung Wuring

Sumber: Observasi Lapangan, 2017

\section{Tinjauan Spasial Permukiman}

Data di kantor kelurahan Wolomarang memperlihatkan bahwa kampung Wuring pada tahun 2017 dihuni oleh 3018 jiwa penduduk dengan $715 \mathrm{KK}$ dan didominasi oleh warga keturunan suku Bajo yang bermata pencaharian sebagai nelayan.

Tata letak hunian orang Bajo di Wuring dibangun berdekatan, seperti yang terlihat di bagian Wuring Tengah. Jarak antara satu hunian panggung dengan hunian panggung lainnya kurang lebih 1,5-2 meter dengan tinggi rata-rata sekitar 2-4 meter. Semakin ke tengah laut, hunian semakin tinggi karena dataran yang mulai melandai, sedangkan hunian di Wuring Laut masih cukup jarang dan masih terdapat ruang-ruang kosong untuk dibangun hunian yang baru. Saat ini hunian suku Bajo di kampung Wuring diklasifikasi dalam dua kelompok meliputi:
1) Kelompok hunian diatas tanah atau daratan hasil timbunan.

Semua hunian di kiri kanan jalan utama dan jalan lingkungan lainnya merupakan hunian di atas tanah. Memiliki teras depan beratap dan halaman belakang yang merupakan ruang terbuka. Ruang disamping dimanfaatkan sebagai jalan penghubung lingkungan dan pada ruang dibawah dimanfaatkan untuk menyimpan barang atau untuk kegiatan rekreasi maupun ekonomis lainya.

2) Kelompok hunian diatas laut yang terdampak pasang surut.

Memiliki teras depan beratap atau hanya teritisan yang lebar. Pada ruang air setelah tatambe ada area untuk menambatkan perahu. Salah satu ruang disamping dimanfaatkan sebagai jalan setapak. Hunian di kelompok ini, khusunya yang berada di bagian tengah umumnya tidak memiliki ruang tatambe karena keterbatasan lahan dimana ruang dibelakang sudah menjadi lahan hunian bagi masyarakat yang tinggal di belakangnya. Adapula ruang untuk penjemuran yang dibangun menyatu dengan tatambe belakang maupun depan dan di samping jika masih terdapat ruang kosong.

Di kampung Wuring terdapat 662 unit hunian yang terdapat di Wuring Leko, Wuring Tengah dan Wuring Laut serta dipilih sebanyak 24 kasus hunian sebagai sampel untuk kajian. 


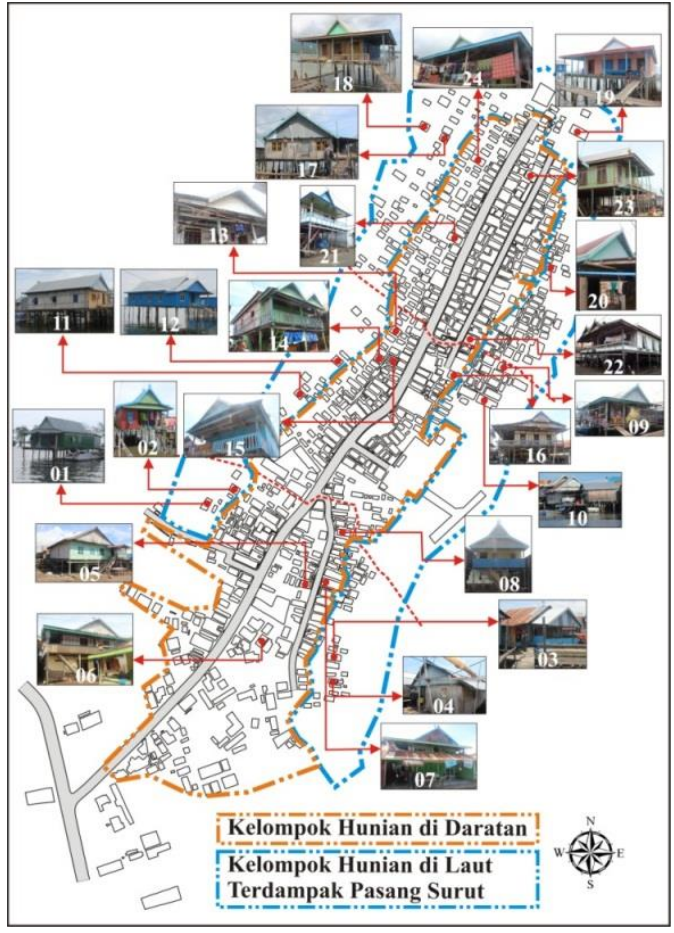

Gambar 4. Kasus hunian suku Bajo

Sumber : Observasi Lapangan, 2017

Berdasarkan hasil wawancara kepada 24 warga (kasus hunian) dan divalidasi dengan wawancara mendalam kepada tujuh key person sesepuh (kasus hunian 04,05,09,13,15,17,22), dapat dijelaskan bahwa bentuk awal hunian suku Bajo di kampung Wuring adalah bentuk panggung tunggal, dimana oleh masyarakat setempat disebut dengan roma toloh. Cirikhas dari arsitektur Suku Bajo awal adalah bentuk struktur yang simetri dan ortogonal pada denah (horizontal) dan potongan (vertikal). Pada arsitektur Suku Bajo, bundaangbuliang dan rumak-diaruma dianggap sebagai ruang utama dalam komposisi bangunan hunian secara keseluruhan.

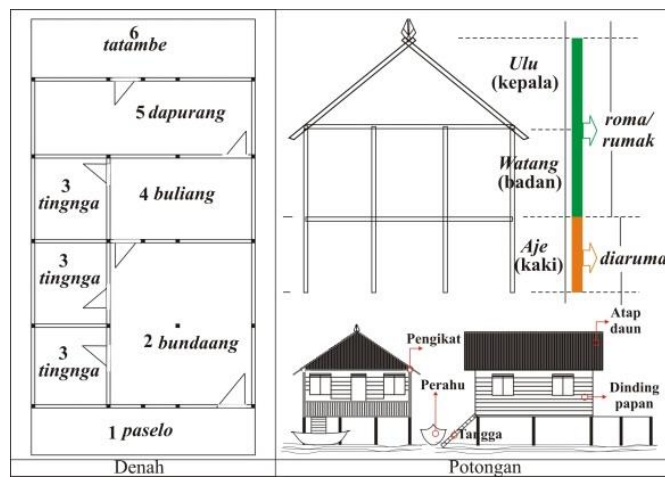

Gambar 5. Bentuk awal hunian suku Bajo

Sumber: Hasil Wawancara Key Person, 2017

Rona Lingkungan (Setting) Aktivitas

Aspek-aspek non fisik yang melandasi terbentuknya rona lingkungan dan tatanan ruang (setting spasial) permukiman Suku Bajo meliputi :

a. Pada aspek ruang menunjukan bahwa ada keterkaitan antar ruangruang kegiatan dalam skala mikro yaitu rumah atau hunian masyarakat dan messo yaitu fasilitas publik seperti tempat penjemuran ikan, pelabuhan ikan, tempat pelelangan ikan dan pasar.

b. Ada pembagian waktu aktivitas masyarakat yaitu pada pukul 11.0014.00 wita hanya terlihat kaum wanita dan anak-anak di kampung Wuring sekedar berkumpul dan bercengkerama atau menjemur ikan di sekitar lingkungan atau ruang hunian seperti di pekarangan, diaruma, paselo maupun tatambe sambil menunggu para suami kembali dari melaut. Di ruang messo pada pukul 15.00-19.00 wita kampung Wuring mulai terlihat ramai dengan berbagai kesibukan terutama para wanita yang menyiapkan dagangan seperti jajanan maupun hasil tangkapan para pria untuk di jual di pasar.

c. Aktivitas yang dilakukan misalnya musyawarah nelayan dan kelompoknya sebelum melaut atau sekedar berkumpul bersama biasa dilakukan di ruang diaruma ataupun 
paselo. Selain itu ada juga ritual macca (baca doa), dimana kaum pria akan menempati bundaang (ruang depan) dan kaum wanita akan menempati buliang (ruang belakang).

d. Pelaku aktivitas yaitu masyarakat Suku Bajo dari kelompok pria dan wanita dewasa dimana ada spesifikasi jenis aktivitas.

e. Ada faktor sosial budaya lainnya yang melandasi pembentukan spasial hunian antara lain karena faktor internal meliputi tingkat pendidikan, pendapatan, bertambah atau berkurangnya jumlah anggota keluarga serta faktor eksternal meliputi lingkungan alam, pengaruh budaya lain dan intervensi pemerintah.

\section{Perkembangan Spasial}

Perkembangan spasial hunian di pesisir Wuring ini dapat dijelaskan dalam beberapa temuan antara lain :

a. Munculnya hunian bentuk panggung tumbuh di beberapa kasus hunian yang dibangun di atas ruang tatambe sebagai suatu usaha pemenuhan kebutuhan tempat tinggal bagi keluarga baru ataupun juga bagi sanak keluarga baru.

b. Ruang tatambe menjadi ruang yang sangat dinamis dalam perkembangan spasial hunian dan memberikan efek terhadap perkembangan ruang messo dan makro karena dapat dikembangkan menjadi fungsi baru yaitu rumah tumbuh untuk tempat tinggal, dapur, kamar mandi, tempat cuci.

c. Fungsi diaruma yang bervariasi dapat ditemukan pada hunian yang berada di darat sedangkan diaruma pada hunian di atas laut hanya berfungsi sebagai tempat parkir sampan dan pemasangan keramba agar lebih mudah diawasi. d. Secara umum, perkembangan spasial hunian secara mikro adalah konsep ma'bunda-ma'buli yang berkembang dengan munculnya ruang dengan fungsi baru serta hunian bentuk panggung tumbuh dan panggung diaruma yang berdampak terhadap tatanan ruang messo lingkungan.

Kondisi spasial hunian yang berkembang ini menyebabkan bentuk hunian sudah bergeser dari bentuk awal menurut hasil wawancara yang dilakukan. Perkembangan spasial hunian dikategorisasi dalam 3 (tiga) bentuk yaitu:

\section{a. Panggung Tunggal}

Hunian bentuk panggung di darat dan di atas laut dengan pemanfaatan ruang hanya pada bagian roma atau rumak. Secara vertikal, pemanfaaatan ruang hunian pada bagian watan (badan) dan ulu kepala). Oleh masyarakat Suku Bajo biasa disebut roma toloh. Perkembangan spasial hunian bentuk panggung tunggal ini lebih kepada pengolahan ruang mikro terutama pada bagian bundaang dan buliang serta tambahan ruang penunjang berupa kamar mandi dan WC. Ruang bundaang mengambil satu bagian ruang sehingga terlihat lebih luas. Ruang yang luas ini sangat multifungsi selain menerima tamu juga untuk mendukung berbagai aktivitas seperti ritual macca, dan sewaktu-waktu dapat berfungsi sebagai tempat tidur atau dimanfaatkan menjadi kamar pengantin jika ada ritual perkawinan. Ruang buliang menjadi lebih luas dan terbuka menyatu dengan dapurang. Modifikasi ruang dalam lainnya yang tidak lazim pada hunian panggung berupa ruang penunjang yaitu $\mathrm{km} / \mathrm{wc}$. 


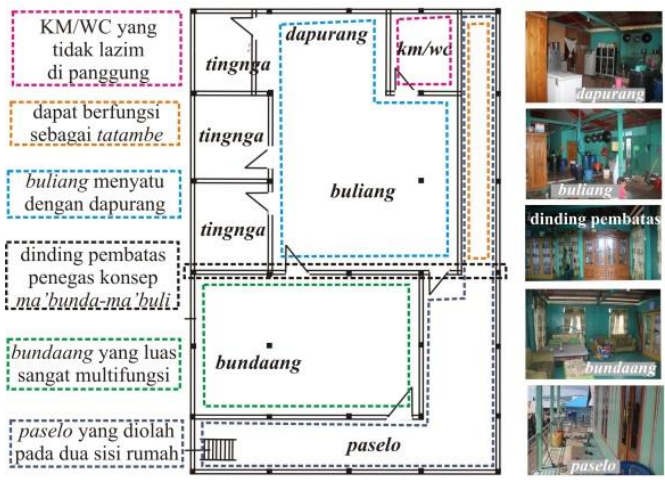

Gambar 6. Perkembangan spasial hunian panggung tunggal

Sumber: Hasil Analisis, 2017

Secara vertikal, pemanfaaatan ruang hunian secara permanen hanya pada bagian watan (badan) dan ulu (kepala) atau bagian roma, sedangkan pemanfaatan pada bagian aje (kaki) atau bagian diaruma untuk rumahrumah di darat hanya bersifat sementara. Pemanfaatan temporer pada bagian diaruma di jam-jam tertentu lebih banyak oleh kaum perempuan dan anak-anak sekedar berkumpul dan bercengkerama atau dijadikan sebagai ruang ekonomi.

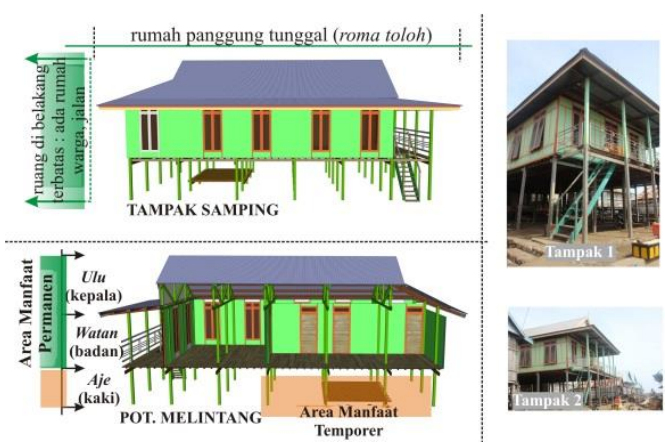

Gambar 7. Pola pemanfaatan hunian panggung tunggal

Sumber: Hasil Analisis, 2017

\section{b. Panggung Tumbuh}

Hunian bentuk panggung di darat dan di atas laut dengan pemanfaatan ruang pada bagian roma atau rumak dan bagian tatambe yang dikembangkan atau dibangun bangunan baru untuk penghuni baru ataupun fungsi lain. Pengembangan tatambe ini menunjukan hunian bertumbu. Rumah tumbuh ini memiliki ukuran yang lebih kecil dari rumah induk. Perkembangan spasial hunian ini terjadi diatas ruang tatambe dan mengindikasikan kebutuhan ruang tempat tinggal bagi anggota keluarga yang banyak ataupun bagi sanak keluarga yang baru datang. Untuk mengatasi kebutuhan tempat tinggal bagi anggota keluarga, maka dibangun rumah panggung tumbuh di atas tatambe yang dimanfatkan oleh sang cucu untuk tempat tinggal bersama keluarganya. Bahwa kekerabatan dan kekeluargaan menjadi aspek utama dalam mendorong pengembangan rumahnya, disamping ketersediaan lahan dan aspek ekonomi yang mendukung. Fungsi-fungsi ruang pada bagian yang bertumbuh ini hampir sama dengan ruang-ruang di rumah induk (roma toloh), namun keduanya merupakan satu kesatuan hunian karena bertumbuh dari rumah induk.

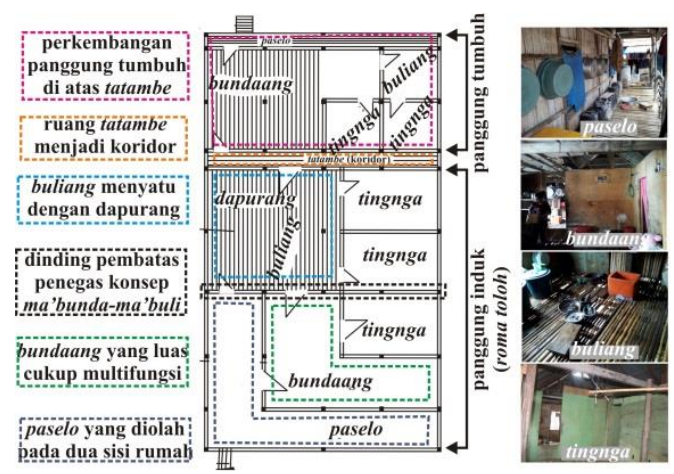

Gambar 8. Perkembangan spasial hunian panggung tumbuh

Sumber: Hasil Analisis, 2017

Secara vertikal, pemanfaaatan ruang hunian pada bagian watan (badan) dan ulu (kepala) atau bagian roma, sedangkan pada bagian aje (kaki) atau bagian diaruma hanya bersifat temporer baik pada hunian yang berada di darat maupun di atas laut. Kecenderungan pemanfaatan sangat berbeda antara keduanya, bahkan rumah di darat akan lebih masif 
berkembang jika ruang diaruma ini berpotensi untuk perkembangan kualitas kehidupan secara ekonomi dan sosial kemasyarakatan. Selain itu dampak signifikan terhadap spasial messo lingkungan yaitu pada hunian panggung tumbuh di atas laut karena hunian akan berkembang secara horizontal dan berdampak pada pemanfaatan lahan di atas laut untuk hunian baru. Kondisi perkembangan spasial hunian seperti ini dapat dianalogikan seperti makhluk hidup yang berkembang biak, sehingga semakin meningkatkan populasinya. Suku Bajo memiliki filosofi sama di lao (laut milik orang Bajo), sehingga pemaknaan ruang laut sebagai ruang yang bebas dan dapat dengan mudah dimanfatkan untuk perkembangan hunian mereka.

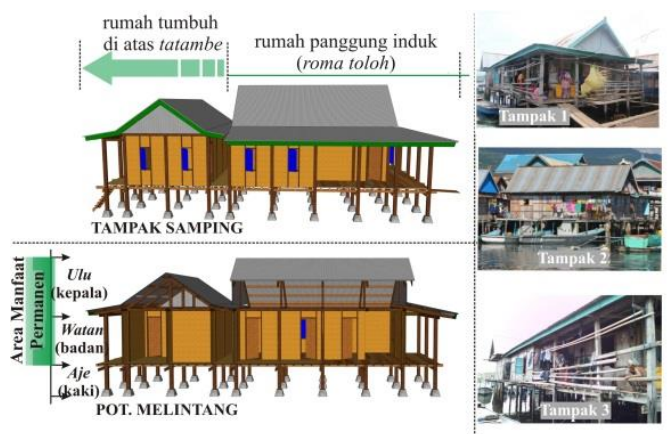

Gambar 9. Pola pemanfaatan hunian panggung tumbuh

Sumber: Hasil Analisis, 2017

Hunian bentuk panggung di darat dengan pemanfaatan ruang secara permanen pada bagian roma atau rumak serta pemanfaatan ruang diaruma (bagian bawah rumak) yang dikembangkan atau dibangun menjadi ruang-ruang dengan fungsi tertentu seperti ruang tidur, dapur, gudang, kamar mandi dan toilet. Perkembangan spasial hunian pada bentuk panggung diaruma ini sangat masif pengolahan ruang pada bagian aje (kaki). Kecenderungan perkembangan hunian ini dengan motif yang hampir sama dengan hunian panggung tumbuh yaitu memenuhi kebutuhan ruang, namun fungsi ruang lebih dominan sebagai pelengkap atau penunjang bagi rumah induk di bagian roma atau rumak. Spasial hunian pada bentuk panggung diaruma ini juga memiliki peran dan kontribusi dalam mengubah tatanan ruang secara mikro hunian maupun messo lingkungan. Namun perkembangan spasial hunian pada bagian diaruma ini lebih berfungsi ekonomis dimanfaatkan untuk tempat berjualan atau gudang hasil tangkapan dalam usaha peningkatan taraf kehidupan masyarakat. Secara spasial hunian berkembang ke bawah pada bagian diaruma.

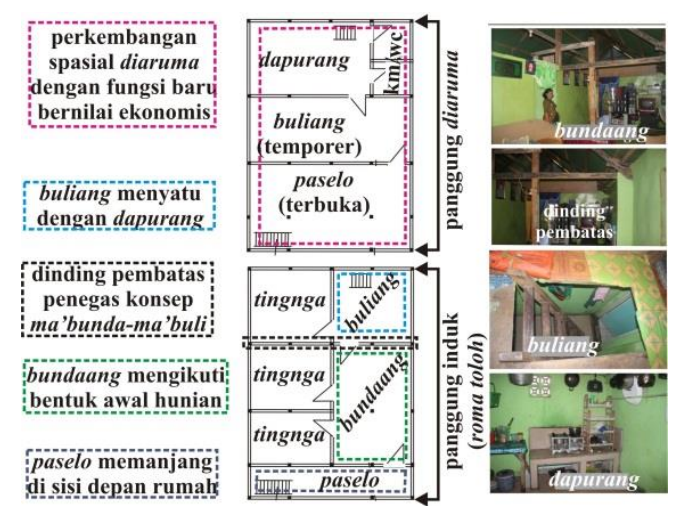

Gambar 10. Perkembangan spasial hunian panggung diaruma

Sumber: Hasil Analisis, 2017

Ruang dengan fungsi baru yang permanen pada bagian diaruma ini menunjukan perkembangan spasial hunian bentuk panggung diaruma tersebut. Secara vertikal, pemanfaaatan ruang hunian oleh masyarakat Suku Bajo pada bagian aje (kaki), watan (badan) dan ulu (kepala) secara permanen dan hanya terjadi pada hunian yang ada di darat. Bagian diaruma diolah secara masif dengan ruang-ruang yang mampu berfungsi secara sosial maupun ekonomis. Pemanfaatan diaruma sebagai jawaban atas kebutuhan ruang untuk berbagai jenis aktivitas kehidupan. Pemanfaatan 
ruang diaruma tercipta dengan gubahan ruang yang bebas. Hunian dengan perkembangan spasial bentuk panggung diaruma ini terdapat pada masyarakat dengan latar belakang ekonomi yang cukup dan faktor sosial lainnya misalnya beberapa kepala keluarga yang menempati satu rumah bersama.
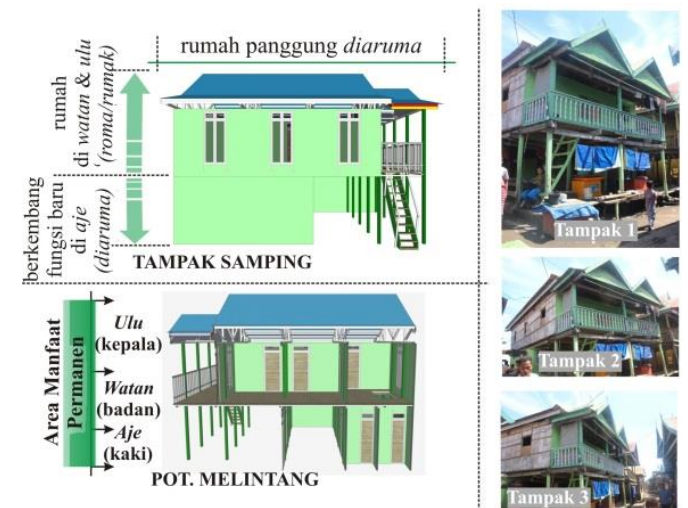

Gambar 11. Pola pemanfaatan hunian panggung diaruma

Sumber: Hasil Analisis, 2017

\section{Sistem Spasial Hunian}

a. Organisasi Ruang Hunian

Pola organisasi ruang mikro (hunian atau rumah tinggal) masyarakat berdampak pada perkembangan ruang messo maupun makro kawasan kampung Wuring, karena hunian yang dibangun khususnya di atas laut selalu dibarengi dengan motif penguasaan lahan di belakang dan di samping yaitu dengan adanya tatambe (teras belakang) dan hunian baru juga didukung dengan keberadaan taka yang masih luas dan menjorok ke arah utara, sehingga taka juga berpotensi ditimbun dan menjadi daratan.

Indikasi yang didapatkan bahwa organisasi ruang mikro ini terbentuk secara linier memanjang dari depan ke belakang yang terdiri dari beberapa ruang utama yaitu paselo (teras depan), bundaang (ruang tamu), tingnga (ruang tidur), buliang (ruang keluarga), dapurang (dapur), tatambe (teras belakang).

Ada dua bagian besar yang mengorganisasi ruang-ruang tersebut di atas yaitu bagian depan yang diwakili oleh bundaang dan bagian belakang diwakili oleh buliang, sehingga oleh masyarakat suku Bajo lebih populer disebut dengan ma'bunda dan ma'buli.

Jika terjadi perkembangan spasial hunian, maka organisasi ruang hunian akan menjadi lebih kompleks dan masif karena dalam satu hunian terdapat dua organisasi ruang seperti pada hunian bentuk panggung tumbuh dan diaruma.

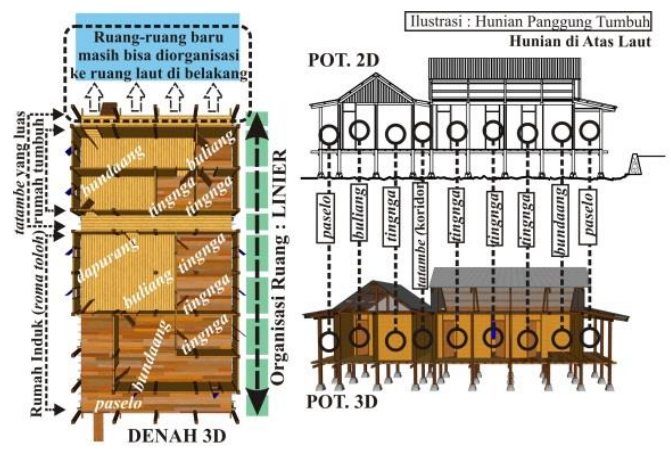

Gambar 12. Organisasi ruang hunian

Sumber: Hasil Analisis, 2017

b. Orientasi Ruang Hunian

Kajian orientasi ruang dilihat dalam tinjauan secara messo lingkungan dan mikro hunian. Orientasi ruang menunjukan pada sebuah ruang, pada jalur sirkulasi dan pada sumbu imajiner. Perbedaan orientasi ruang juga terlihat pada hunian di darat dan di atas laut. Jika hunian di darat berorientasi pada suatu sumbu imajiner berupa susunan rumahrumah di depannya atau pada jaringan sirkulasi berupa jalan yang berada di depan, maka rumah di atas laut memiliki keunikan khususnya pada fenomena rumah tumbuh, misalnya pada kasus rumah 009 terlihat rumah induk berorientasi pada jaringan sirkulasi dan susunan 
rumah-rumah di depannya sedangkan rumah tumbuh berorientasi pada sebuah ruang berupa ruang laut. Jadi rumah tumbuh dijadikan sebagai teras untuk akses ke laut bagi rumah induk didepannya.

Orientasi ruang hunian dapat memberikan pengaruh terhadap perkembangan spasial hunian. Misalnya orientasi pada sumbu imajiner yaitu letak hunian yang berderet dengan hunian lain di samping dan di belakang menyebabkan rumah agak sulit untuk dikembangkan karena tidak ada lagi ruang di samping maupun di belakang. Berbeda dengan orientasi ruang hunian pada sebuah ruang yaitu ruang laut akan lebih leluasa terjadi perkembangan spasialnya, misalnya pada hunian bentuk panggung tumbuh yang terletak di atas laut.

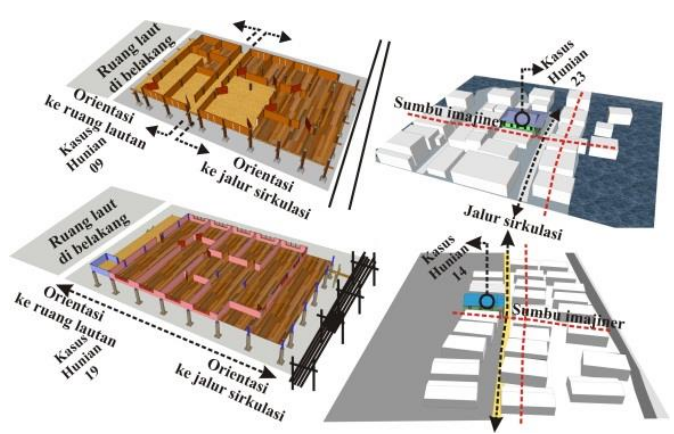

Gambar 13. Orientasi ruang messo lingkungan hunian

Sumber: Hasil Analisis, 2017

Orientasi ruang dalam hunian dapat dijelaskan bahwa ada ruang tertentu khususnya ruang tidur (tingnga) tersusun secara linear atau berorientasi pada sebuah ruang yaitu ruang tidur di belakang selalu sejajar dengan ruang tidur di depannya serta arah hadapnya pada ruang bundaang dan buliang di depannya. Hal ini telihat sama dengan susunan rumah-rumah pada orientasi ruang luar.

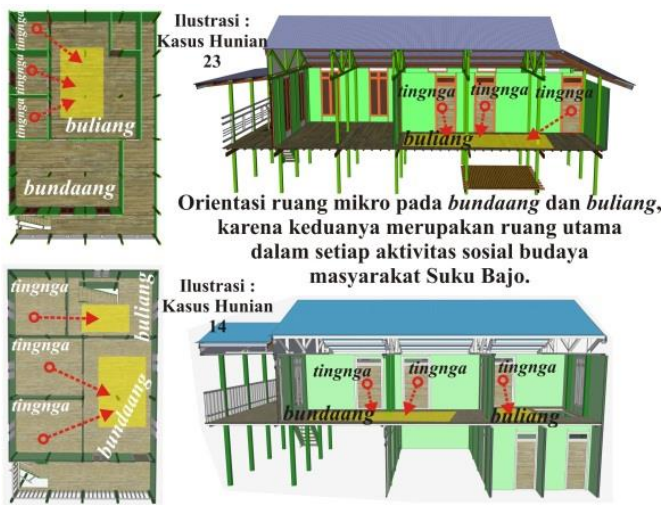

Gambar 14. Orientasi ruang mikro hunian Sumber : Hasil Analisis, 2017

c. Hirarki Ruang Hunian

Secara hirarkis, ruang-ruang dalam hunian Suku Bajo dibagi dalam 2 (dua) bagian besar yaitu bundaang (ruang depan) dan buliang (ruang belakang). Bundaang dan buliang merupakan dua bagian ruang yang harus ada dalam rumah-rumah suku Bajo karena keduanya memberikan makna hirarki ruang dalam hunian pada setiap upacara atau ritual adat yang dilakukan dalam rumah. Adapula rumah tinggal yang tidak lagi memiliki batasan jelas antara ruang depan (bundaang) dan ruang belakang (buliang) dikarenakan perkembangan sosial budaya dan tingkat ekonomi yang melatarbelakanginya.

Fenomena ma'bunda-ma'buli menempatkan bundaang dan buliang sebagai dua bagian besar tata ruang dalam hunian suku Bajo, karena masing-masing bagian mengorganiasi beberapa ruang yaitu ma'bundaang yang bersifat semi publik terdiri dari ruang tamu, teras dan ruang tidur bagian depan sedangkan ma'buliang yang bersifat semi privat terdiri dari ruang keluarga, ruang tidur bagian belakang, dapur dan teras belakang. 


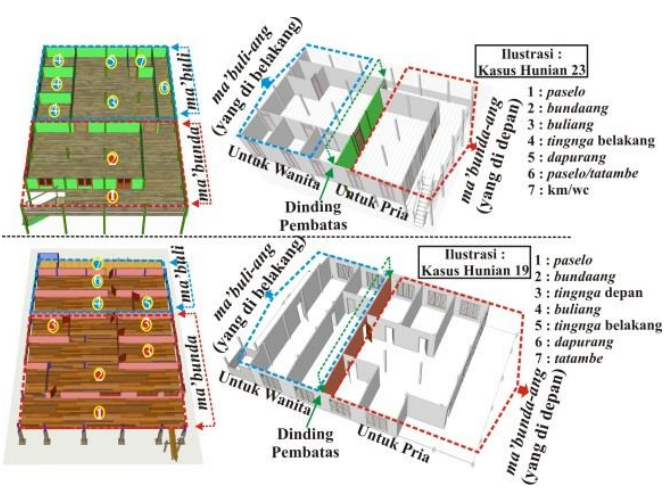

Gambar 15. Hirarki ruang hunian

Sumber: Hasil Analisis, 2017

Namun dalam keseharian masyarakat Suku Bajo, penyebutan bundaang lebih diasosiasikan untuk ruang tamu dan buliang diasosiasikan untuk ruang keluarga. Fenomena ma'bunda (bagi kaum pria) dan ma'buli (bagi kaum wanita) ini juga merupakan perwujudan dari pola pembagian tempat sholat dalam ruang masjid yaitu ada pemisahan antara pria dan wanita. Bundaang dan buliang merupakan ruang utama pada setiap rumah suku Bajo.

Perkembangan spasial hunian juga memberikan dampak yang signifikan dalam gubahan runag mikro hunian dan hirarki ruang hunian. Dampak hirarki ruang yang terjadi pada hunian dengan perkembangan spasial yang masif seperti panggung tumbuh dan panggung diaruma lebih kepada letak ruang-ruang mikro yang cenderung tidak beraturan misalnya dapurang dan buliang yang sudah menyatu serta fungsi ganda dari ruang paselo yang dapat menjadi tatambe.

Tabel 1. Susunan hirarki ruang hunian suku Bajo di kampung Wuring

\begin{tabular}{|c|c|c|c|c|c|c|c|c|}
\hline \multirow[b]{2}{*}{ No } & \multirow[b]{2}{*}{$\begin{array}{l}\text { Nama } \\
\text { Ruang }\end{array}$} & \multicolumn{5}{|c|}{ Hirarki Ruang } & \multicolumn{2}{|c|}{ Bagian Ruang } \\
\hline & & Privat & $\begin{array}{l}\text { Semi } \\
\text { Privat }\end{array}$ & Publik & $\begin{array}{l}\text { Semi } \\
\text { Publik }\end{array}$ & Service & $\begin{array}{l}\text { Bag. depan } \\
\text { (ma'bunda) }\end{array}$ & $\begin{array}{c}\text { Bag. } \\
\text { belakang } \\
\text { (ma'buli) }\end{array}$ \\
\hline 1 & Paselo & & & $\checkmark$ & & & $\checkmark$ & \\
\hline 2 & Bundaang & & & & $\checkmark$ & & $\checkmark$ & \\
\hline 3 & $\begin{array}{l}\text { Tingnga } \\
\text { depan }\end{array}$ & $\checkmark$ & & & & & $\checkmark$ & \\
\hline 4 & Buliang & & $\checkmark$ & & & & & $\checkmark$ \\
\hline 5 & $\begin{array}{l}\text { Tingnga } \\
\text { belakang }\end{array}$ & $\checkmark$ & & & & & & $\checkmark$ \\
\hline 6 & Dapurang & & $\checkmark$ & & & & & $\checkmark$ \\
\hline 7 & Tatambe & & & & $\checkmark$ & & & $\checkmark$ \\
\hline 8 & KM/WC & & & & & $\checkmark$ & & $\checkmark$ \\
\hline
\end{tabular}

\section{Kesimpulan}

Berdasarkan hasil dan pembahasan maka dapat disimpulkan bahwa perkembangan spasial yang terbentuk pada hunian Suku Bajo di pesisir Wuring Kota Maumere meliputi perkembangan spasial hunian pada bentuk panggung tunggal, panggung tumbuh dan panggung diaruma. Pada ruang mikro hunian ditemukan konsep ma'bunda-ma'buli. Perkembangan pada sistem spasial (bentukan organisasi, orientasi dan hirarki ruang hunian) berdasarkan pada aspek-aspek setting spasial (implikasi aktivitas, waktu dan pelaku aktivitas pada ruang atau spasial hunian). Secara umum perkembangan spasial dalam bentukan mikro hunian berdampak pada ruang 
messo lingkungan yang dilandasi beberapa aspek non fisik atau aspek sosial budaya masyarakat Suku Bajo seperti kekerabatan atau kekeluargaan (bertambahnya jumlah anggota keluarga), jenis aktivitas dan pelaku aktivitas, tingkat ekonomi masyarakat (pembiayaan pembangunan hunian), proses asimilasi budaya dan intervensi pemerintah Kabupaten Sikka.

\section{Daftar Pustaka}

Antariksa. (2011, Februari 18). Pengaruh kebudayaan dan adat istiadat masyarakat dalam permukiman tradisional. diakses 12 Oktober 2016, dari antariksaarticle.blogspot.com.

Ciptadi, Wahyudin. (2014). Perubahan pola organisasi, hirarki dan orientasi ruang rumah tinggal tradisional melayu Pontianak tipe potong limas di sekitar komplek Kraton Kadriyah Pontianak. Jurnal Vokasi, X(2), 89-97.

Habraken, N. J. (1978). General principles about the way built environment exist. Massachusetts: MIT Press.

Nugroho, Agung Murti. (2015). Keberlanjutan ruang binaan nusantara di wilayah pesisir. Dalam Wuisang, Cynthia \& Kumurur, Veronica (Ed.), Prosiding Temu Ilmiah IPLBI: B039-B044. Manado: Universitas Sam Ratulangi.

Prihanto, Teguh. (2008). Pengaruh kehidupan sosio-kultural terhadap spasial permukiman di Kelurahan Sekaran sebagai daerah pinggiran Kota Semarang. Jurnal Teknik Sipil dan Perencanaan, X(2), 93102.

Rapoport, Amos. (1990). System of activities and system of settings, Dalam Kent (Ed.). Domestic
Architecture and The Use of Space. Cambridge: Cambridge University Press.

Turner, John F. C. (1972). Freedom to build: dweller control of the housing process. New York: Macmillan. 
Jurnal Teknik Arsitektur ARTEKS, Volume. 2, Nomor 1, Desember 2017 ISSN 2541-0598 